\title{
212 MART; Is it Able o Create Economical Impacts, Engage Society and Develop Entrepreneurship Culture Within Cociety?
}

\author{
Didi Mulyadi ${ }^{1 *}$, Fauzhobihi ${ }^{2}$ \\ ${ }^{1,2}$ Faculty of Management, School of Economics Pertiwi, \\ Jl. Ir. H. Juanda No. 133 Bekasi,West Java 17121, Indonesia \\ * Corresponding author: \\ Email: didi.mulyadi@pertiwi.ac.id
}

\begin{abstract}
.
This studies is aimed at analyzing the influence of 212 Mart in developing economic impacts, social engagement and entrepreneurship culture within Moslems society measured by the involvement in the establishment of the 212 Mart. The data were taken from 2 of the 212 Mart located in Bekasi using qualitative and descriptive quantitative in which the interview and questionnaires were conducted simultaneously to gain the needed data. The result found that from the economic impacts, the 212 Mart has not provided the expected results as it needed 4 years return on investment, and the engaging society the Mart has taken into effect the collaboration and cooperation among the members and people in its surrounding while the developing entrepreneurship culture, the 212 Mart has actually brought the energy of togetherness among members as it was built with at least 50-100 investors.
\end{abstract}

Keywords: 212 Mart, Economical impacts, social engagement, entrepreneurship culture, profitability

\section{INTRODUCTION}

In a changing environment, firms need to innovate to not only create new value but also preserve their competitiveness [1]. One of the ways to gain competitiveness is by involving community in the business practice [1]. Sharia cooperative 212 is one of the models set up by Muslim leaders to implement the spirit of Action 212 which is full of brotherhood and unity. Brotherhood and unity are words that reflects the economic impacts.

This spirit was later expressed in efforts to turn the 212 Sharia Cooperative into a place for economic struggle to achieve people's economic independence [2]. This model has actually been practiced by Indian company namely Project Shakti implemented by Hindustan Lever, which has enabled poor rural women to become distributors of branded products in villages [3].

Community-based, social and societal entrepreneurship have increased in importance in the past decade as globally more people and organizations are interested in issues related to how to encourage a sustainable world for future generations [4]. It's http://ijstm.inarah.co.id 
named sharing economy in which it is an emerging economic model usually defined as a peer-to-peer based sharing of access to goods and services [5], [6]. "Although much has been written about the promise of CC [collaborative economy) or Sharing Economy in this article] and its potential benefits, it is a largely under-researched area and relatively little is known about its true impact on society, the economy, and the environment."

With its mission the Sharia Cooperative is expected to optimize all economic and human resources potential in terms of purchasing power, production, distribution, capital fertilization and investment in selected productive sectors carried out in congregations, in a trustworthy, professional manner capable of bringing prosperity to the level of individuals / families and in achieving glory at the level of public welfare [7], [8]

The collaboration with suppliers and customers offers the potential to significantly reduce costs and improve service benefits [9]. The goal of the Sharia cooperative is building a trusted, professional, large and strong economy for people as one of the pillars of worship, sharia and propaganda towards world happiness and the safety of the future [2]. There are three important values developed by 212 Sharia Cooperative namely Amanah, Berjamaah and Izzah. Amanah means that Sharia Cooperative 212 management must be carried out with full trust. All people involved in it must be competent human resources. Management must be equipped with a set of excellent System Operating Procedure (SOP) and manuals. Management must be accompanied by the Sharia Supervisory Board, Advisors and Supervisors as well as various complementary Committees such as the Investment Committee, Audit Committee and Remuneration and Promotion Committee. The management are periodically required to provide reports to members, regulators and the public.[2] Berjamaah means that Sharia Cooperative 212 must be able to accommodate the potential and aspirations of the economic revival of Muslims in particular, and of the Indonesian people in general, as far as possible. This cooperative needs to be owned jointly, not controlled by just a handful of individuals or groups. Sharia Cooperative 212 must also offer benefits to as many Indonesian Muslims as possible.[2] This concept is also related with how the transformation of economy were based on the productivity of the society [10] Izzah is Glory. In the level of individual glory means the fulfillment of all the needs of food, shelter, education, health and transportation of members. Indonesia and the Islamic ummah at nation level must become a dignified and economically independent nation. This is reflected in food and energy selfsufficiency, high exports, trade balance surpluses, poor gini ratios, low absolute unemployment and the smaller the number of poor and poor families [2] 212 Mart is one of the products developed by Sharia Cooperative. Comparing to those Moslems living in Indonesia, the 212 Mart must actually be easy to penetrate the market and gain more capital but the fact the development of the 212 Mart is far behind those two market leaders in the industry, Indomaret and Alfamart which can establish more than 1,000 outlets a year. 
Table 1 : The Number of Outlets of Retail Supermarkets (https://databoks.katadata.co.id/, 2019)

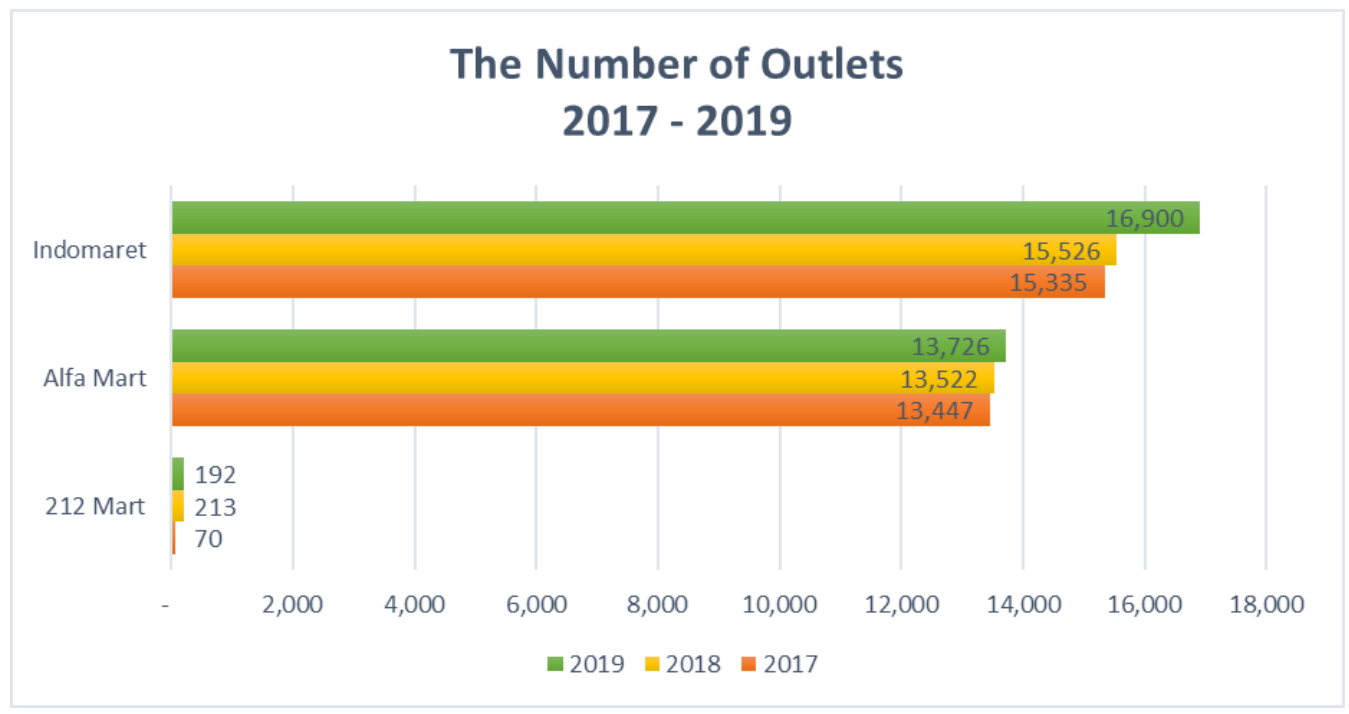

The data shows that in 2017 as the 212 Mart was first established numbering less than 100 outlets compared to those Indomaret with 15,335 outlets and Alafamart with 13,447 outlets. In 2018 the 212 Mart doubled the number to 213 outlets while Indomaret and Alfamart number 15,526 and 13,522 respectively. And the last data in 2019, 212 Mart declines to 192 outlets compared to 16,900 and 13,726 for Indimaret and Alfamart..

The above data certainly can not be used as a benchmark, because Indomaret and Alfamart have been active in the retail business for a long time. But 212 Mart should grow faster with the concept of unity, because the market and its investors are available. With the number of Muslims representing over $85 \%$ of the total population, this 212 Mart should be much more developed than it is todaylt also analyzes the concept and strategy of "racial economic cooperation" combining cooperative industries and services in a "group economy [12].

Most of Moslems are struggling in economics activities and economic conditions continue to lag behind Chinese populations. Chinese ethic gains power on Indonesia economic and currently only $1 \%$ of the population. The 2018 World Bank report, which states that 1 per cent of Indonesians control 50.3 per cent or just 10 per cent but control 77 per cent of national assets, is proof of their domination in the country [13].

But of course the existence of 212 Mart is seen not only from the business concept but also how the 212 Mart can have an economic impact, unite the Islamic community and develop an entrepreneurial spirit. This research aimed to examine the questions how 212 Mart is able to provide economic impacts, unite the Ummah and develop the entrepreneurial spirit among Moslems [14].

This research shall result in an answer whether the concept of sharing economy developed through 212 Mart can gain the public interest. The limitation of the research 
International Journal Of Science, Technology \& Management

lies on the limited research objects which consist only two of the hundreds outlets in Indonesia. This result can be used for further research.

\section{METHODS}

This study conducted in Bekasi, Indonesia taking two of the 212 Mart as research objects between May $1^{\text {st }}$ until May $30^{\text {th }}$. The research participants were 2 managers of the researched shop, 25 investors of each shop and the society surrounding the operation of the shops. The data were gained through interviews and questionnaires distributed to those taking part on this business. The interview data were then reduced, displayed, coded and analyzed and finally concluded [15]-[17]. While the data from the questionnaires were included as a secondary data supporting the interview results.

\section{RESULT AND DISCUSSION Economic Impacts}

The results showed that the economic impact was not very significant. That can be seen from return on investment process which takes more than four years. Compared to those in similar industry offering shorter period of the return on investment. The longer time on the return of investment can lead to weak investment attractiveness of the community, in particular, among Muslims to invest in this 212 Mart. When viewed from the large number of members, returns on investment should be faster so it becomes a good attraction for this 212 Mart's promotion and expansion. Every month the store should have a huge turnover with an average investor exceeding 100 people and assuming they are shopping at the store.

In terms of profit sharing, the model developed by 212 stores is actually sufficient because profit sharing is done once a year or the same as business models that existed where profits are made to the extent of the financial statements reported in those periods or at least that.The advantage of 212 Mart is that space is allocated for goods manufactured by SMEs, but if the number of visitors is small, no buyers will have the displayed goods. 212 Mart also uses the supply system commonly used by other retail systems from the supply side of the goods, so there is no difference to similar stores in the supply system. What could be a little different is that this 212 Mart could become a place for cooperative members who have items to sell at the store as a supply chain

The goods entrusted can be displayed with a system of consignment, where the shop will pay for the items entrusted after being sold. Another advantage of the 212 Mart is that this shop can be used as a supply chain for community-produced goods, because it is in line with the cooperative's vision and mission. The observations made were not significantly visible to the goods manufactured by SMEs, i.e. only about 20 percent of the total space, while the remaining 80 percent were used by goods which also sell similar stores[18]

A research by Nembhard [12] found that there were such kind of the 212 Mart in developing African American economic development. resident ownership and individual and community entrepreneurship address issues of the export of capital and 
industry from cities, to suburbs and overseas [12]. Compared to those of the similar business, the return on investment of the 212 Mart take much longer which makes it less interesting in gaining the investors. With lower interests of the business, it would be very difficult for the management to expand rapidly.

Lazonick and O'Sullivan [19] states that "the principle of retain and reinvest began running into problems for two reasons, one having to do with the growth of the corporation and the other having to do with the rise of new competitors." It can be concluded that the main concept of investors are the growth of the companies and the expansion of the competitors.

The 212 Mart concept does not consider financial factors in doing the business. While it seems that it considers non financial measures. Nadzi, Omar and Rahman [20] states that non-financial measures, including business ownership, happiness, gratification, level of independence, and life improvement, to complement the financial measures in determining the performance of micro entrepreneurs.

\section{Social Cohesion}

Since its establishment, the concept of social cohesion has indeed been felt where every investor has to become a member of a cooperative where the 212 Mart location will be opened. It indirectly creates social communities with the same goals, by joining investors in cooperatives. With the system social cohesion is automatically developed. With at least 100 members coming from the same environment, the relationship between community members in the environment will be better, as evidenced by joint activities such as social gathering and other activities. The involvement of cooperative members who are both citizens in the environment makes it possible to maintain and harmonize the relationship between investors / members of the cooperative and communities.[21]

Another thing that improves social cohesion is to provide compensation for orphans and poor people in the environment around them. 212 Mart can gain sympathy by holding these activities and at the same time become a soft marketing activity for the store. 212 This Mart also gives priority to recruiting employees from the surrounding community. Although the number of people per store is not too many the involvement of the surrounding community in becoming an employee allows the shop to help people without jobs.

Another activity in social cohesion is the creation of traditional stalls as their partners. 212 Mart 's role is as a commodity wholesaler who will be sold through small stalls around 212 Mart. With this model of collaboration it is possible that the small shops around the 212 Mart will support each other and eventually all of them will have the opportunity to earn money By becoming an agent for small stalls around 212 Mart it creates indirect harmony between the same business owners. Don't let 212 Mart 's presence merely make these small shops have to close down their businesses because they can't compete on price. 
This can happen because 212 Mart and the like have a direct network with major suppliers so that the prices they get are also much cheaper, while the small stalls have to pass through several agents so that the selling prices they charge to consumers are much more expensive compared to 212 Mart or the like. If that happens then between business people and the community there will be no harmony or social cohesion. Social entrepreneurship is a process of bringing together resources to address a social need. This involves the active evaluation and pursuit of opportunities as a means for social transformation [4]

The allocation of profits obtained by the store in the form of zakat is another activity in building social cohesion. The allocated value is 2.5 per cent. This is very good to help the community or community activities where the 212 Mart operates. It suits with opinion from Shaw and Carter [22] that states 212 mart model "autonomous organizations often with loose governance and ownership structures, based on participation by clients, users, local community groups or trustees. Profits are distributed to stakeholders or for the benefit of the community. The store has a commitment to the community with this model, which in the end will also give the community a positive response and ultimately want to shop at the store.

By creating activities that stimulate social cohesion can actually be used as an effective marketing solution or model if consistent implementation of the activity model is possible. Community engagement through service-learning experiences creates a gateway to the community as the site for enriched learning [23]. Communities encourage innovative opportunities by discovering untapped social needs and focusing on practices that benefit community members [4].

\section{Entrepreneurship}

212 Mart has succeeded in enhancing the concept of entrepreneurship among Muslim communities. This is reflected in the number of investors involved in each of the 212 Marts. With the concept of at least 100 people in one shop, then indirectly 212 Mart has created 100 new entrepreneurs. Each investor ultimately has the knowledge and skills to become an entrepreneur by being involved in every meeting activity on how to advance a managed store. They can use this not only as an investor in 212 Mart but also as other business activities that those investors will be carrying out. 212 Mart can be a place for them to learn about starting a business.

212 Mart also provides an understanding of how vision and mission are shaped and transformed into operational concepts so that they can be implemented. Even though not all investors are involved in every 212 Mart development, members may learn and understand the business development at every meeting. The concept of entrepreneurship also illustrates how all investors understand the risks that may arise from the value of their investments. Whatever the model in business, not all businesses can always be running as planned. And the entrepreneurial spirit understands only the risks that can result from every step of the business.

Another concept of entrepreneurship is that each investor has a high level of trust before starting the business. 212 It is Mart who guarantees that trust. Without a 
high degree of confidence, prospective entrepreneurs will fear starting a business. From various failures, a strong businessman is always formed but he dares to continue to do so until he succeeds.

The 212 Mart business was also seen by all investors as an opportunity. They think this 212 Mart can be used both as a means of investment and as a charity. This is in line with the 212 Mart vision and mission, where the concept combines the concepts of economic sharing and social engagement and involves many people.

\section{CONCLUSION}

The result of the research proves that 212 Mart has, in some points, provided an alternative choice for collective business collaboration managed by cooperative. The model, even though it's not much different compared with the similar shops, help develop Moslems community in gaining the social cohesion and entrepreneurship culture while for economic impacts it's still on an ongoing development and improvement.

There are a lot of things developed from the 212 Mart in gaining economics impacts not only from the direct profit from the invested money but it can also be gained through the production of the goods or services as members are entitled to also market their products or services through the outlets as meeting the requirements.

From the social cohesion or community engagement, this model might be the one of solutions answering problems faced by people in Indonesia. This model can develop the relationship among members of cooperative which in bigger perspective it could help the whole community in gaining their better relationship.

In developing entrepreneurship culture, this model is actually one of good models that needs to develop especially those for people economically low and can not run the business by their own as limited capital and access to baking system. The cooperative model namely berjamaah make it possible for people who have a very limited money gain profit and knowledge through this model

\section{ACKNOWLEDGMENTS}

This paper recommend that the financial performance of the 212 Mart can be developed its investors loyalty which can be gained by shifting their regular and monthly expenditure from previous market channel to 212 Mart. It can be capitalized if the market has provided better service, quality product and cheaper prices. If the 212 Mart management can capitalize its investors the revenue of the outlet would be huge which result in faster return on investment. This will lead to be more interesting investment tools for others and finally will accelerate the business expansion. With its rapid expansion, the brand of the 212 Mart will also be recognized and later can compete equally with two major players, Alfa Mart and Indomaret. 
The services should also be improved in order to gain attraction from the customers. Compared to those of the two main players, Alfa Mart and Indomaret, 212 Mart services is far lag behind. Form attributes the employees wear and the way they greet customers, the customers can easily determine the professionalism of the business. While the two major players shape the brand from all aspect, the 212 Mart doesn't seem aware of those attributes and attitude. The involvement of the investors should also be encouraged to promote their business to neighbors, friends and colleagues so that the numbers of customers would be as snowballs.

\section{REFERENCES}

[1] V. G. Lange and V. K. Velamuri, "Business model innovation in the retail industry: Growth by serving the silver generation," Int. J. Entrep. Innov. Manag., vol. 18, no. 4, pp. 310-329, 2014, doi: 10.1504/IJEIM.2014.064210.

[2] Koperasi Syariah 212, "Profil 212 Mart." Koperasi Syariah 212, Bogor, 2020.

[3] A. Sorescu, R. T. Frambach, J. Singh, A. Rangaswamy, and C. Bridges, "Innovations in retail business models," J. Retail., vol. 87, no. SUPPL. 1, pp. S3-S16, 2011, doi: 10.1016/j.jretai.2011.04.005.

[4] V. Ratten and I. M. Welpe, "Special issue: Community-based, social and societal entrepreneurship," Entrep. Reg. Dev., vol. 23, no. 5-6, pp. 283-286, 2011, doi: 10.1080/08985626.2011.580159.

[5] Z. Mi and D. M. Coffman, "The sharing economy promotes sustainable societies," Nat. Commun., vol. 10, no. 1, pp. 5-7, 2019, doi: 10.1038/s41467-019-09260-4.

[6] C. E. Cherry and N. F. Pidgeon, "Is sharing the solution? Exploring public acceptability of the sharing economy," J. Clean. Prod., vol. 195, pp. 939-948, 2018, doi: 10.1016/j.jclepro.2018.05.278.

[7] C. Manaf and M. Nuraidi, "Model Pengembangan Koperasi Produsen," J. Ekon. Nas., vol. 1, no. 2, pp. 1-30, 2018.

[8] S. Nafanu, "Model Pengembangan Koperasi Unit Desa (KUD) Berbasis Agribisnis di Pedesaan Swapraja Biboki," Agrimor, vol. 1, no. 02, pp. 30-31, 2016, doi: 10.32938/ag.v1i02.103.

[9] S. Minner, "Bargaining for cooperative economic ordering," Decis. Support Syst., vol. 43, no. 2, pp. 569-583, 2007, doi: 10.1016/j.dss.2005.05.016.

[10] E. Sudiapermana and Muslikhah, "The Transformation of Sustainable Community Empowerment Based," J. Nonform. Educ., vol. 6, no. 1, pp. 36-43, 2020.

[11] Https://databoks.katadata.co.id/, "Data Toko Retails." Databoks, Jakarta, 2019.

[12] J. G. Nembhard, "Cooperative Ownership in the Struggle for African American Economic Empowerment," Humanit. Soc., vol. 28, no. 3, pp. 299-321, 2004.

[13] P. W. Jones, World Bank Financing of Education. Oxon: Routledge, 20007.

[14] Koperasi Syariah 212, "Produk 212." Koperasi Syariah 212, Bogor, 2020.

[15] J. Miles B Matthew, Hubbermean A Michael, Saldana, Qualitative Data Analysis, A Method Sourcebook, 3rd ed. United States: Sage Publishing, 2014.

[16] J. W. Creswell, Educational Reserach. Boston, 2012.

[17] J. C. Creswell, Educational Reserach; Planning, Conducting and Evaluating Quantitative and Qualitative Research, 4th ed. Boston: Pearson Education, 2012.

[18] A. A. Frihatni, "The Existence of Modern Mini Markets amidst Traditional Retail Market," Int. J. Sci. Technol. Manag., vol. 1, no. 3, pp. 244-250, 2020, doi: https://doi.org/10.46729/ijstm.v1i3.57.

[19] W. Lazonick and M. O'Sullivan, "Maximizing shareholder value: A new ideology for corporate governance," Econ. Soc., vol. 29, no. 1, pp. 13-35, 2000, doi: 
10.1080/030851400360541.

[20] F. A. A. Nadzri, N. Omar, and R. A. Rahman, "Enterprise governance of micro entrepreneurs in Malaysia: Comparison between the Amanah Ikhtiar Malaysia and Asnaf's economic development program," Glob. J. Al-Thaqafah, vol. 2018, no. January, pp. 25-40, 2018, doi: 10.7187/gjatsi2018-02.

[21] D. Mulyadi, S. Suryadi, and R. R. Aliyyah, "Life Skills Education Program : Is it Beneficial for the Society?," J. Non Form. Educ., vol. 6, no. 2, pp. 101-106, 2020.

[22] E. Shaw and S. Carter, "Social entrepreneurship: Theoretical antecedents and empirical analysis of entrepreneurial processes and outcomes," J. Small Bus. Enterp. Dev., vol. 14, no. 3, pp. 418-434, 2007, doi: 10.1108/14626000710773529.

[23] C. D. James and C. L. Schmitz, "Transforming Sustainability Education: Ethics, Leadership, Community Engagement, and Social Entrepreneurship," Int. J. Bus. Soc. Sci., vol. 2, no. 5, pp. 1-7, 2011. 